\title{
THE ANALYSIS OF COMPANY'S CAPITAL AND EVALUATION OF FACTORS, WHICH INFLUENCE CREATION OF THE OPTIMAL CAPITAL STRUCTURE
}

\author{
Svetlana Saksonova \\ University of Latvia, 19 Raina Blvd., LV 1586 Riga, Latvia, \\ E-mail: svetlana.saksonova@lu.lv
}

Received 0603 2006; accepted 28042006

\begin{abstract}
In this article, the author will outline several stages of the process of determining optimal capital structure and will concentrate in particular on the first two stages of this process - analysis of company's borrowed capital and equity as well as the evaluation of the main factors, which influence capital structure. It is important to stress these preparatory stages, because successful operation of the company is built on properly understanding the relationship between risk and potential reward that is inherent in different alternatives of capital structure. These stages stress the importance of gathering reliable financial information about the company (enabling calculation of the ratios mentioned in the article) and performing risk analysis (relying in part on the external and internal factors described in the article) in order to decide on the optimal capital structure.

The author cautions that rapid economics growth in Latvia will at least slow down over time. Managers need to take that into account, when planning capital structure and therefore avoid increasing their leverage to dangerous levels.
\end{abstract}

Keywords: optimal capital structure, factors, financial management, risk, potential reward.

\section{Introduction}

Calculation of the full price of all kinds of the newly attracted capital and the resulting judgments on the optimal capital structure are the main criteria for company's financial management, when looking at the alternative ways to finance capital requirements of any company. In this article, the author will outline several stages of the process of determining optimal capital structure and will concentrate in particular on the first two stages of this process - analysis of company's borrowed capital and equity as well as the evaluation of the main factors, which influence capital structure. It is important to stress these preparatory stages, because successful operation of the company is built on properly understanding the relationship between risk and potential reward that is inherent in different alternatives of capital structure.

The structure of long-term capital for any company is usually not homogeneous; it consists of the owned capital (equity) and borrowed resources. Equity consists of the ordinary shares (or ownership interest in case of the Limited Liability Company) and retained earnings of the company. In certain sense depreciation, which can be considered an important source of internal financing for the company, can also be included in equity related capital.

The long-term borrowed capital in most of the developed countries primarily consists of the bonds issued by the company, looking to raise additional finance. For the majority of Latvian companies issuing bonds is still quite uncommon, however, there is currently no equivalent way offered for attracting borrowed funds for longer periods of time e.g. $20-$ 30 years. One of the reasons that the bond market development has been hindered is corporate finance legislation in Latvia, which imposes various limits on bond issuance. Preferred shares, which have the characteristics of both the first and second ways of financing, take an intermediate position between traditional equity and borrowed capital, however in current circumstances, this source of financing for Latvian companies can safely be abstracted from, as it remains relatively unknown [1].

Each of the enumerated types of capital has its own pricing peculiarities, since free resources are obviously 
non-existent. Even earnings and depreciation are costly sources of financing. The payment for the use of those sources consists of dividends, which are paid to the proprietors of the business - shareholders.

One can see that a suitable definition of the total price of company's capital can be summarized as the weighted average of the different costs of different types of capital. In order to calculate the average price of the total capital, one first has to determine the price for each type of capital. Capital structure is characterized by proportions of different capital components in the total of company's capital. By increasing the proportion of relatively cheaper sources of capital, the company can lower the total costs of capital. In practice, it is often evident that the "cheapest" source of capital is borrowed financing.

Creating optimal capital structure, that is determining the most beneficial proportions of equity and borrowed financing in the capital structure, is one of the main tasks for the process of financial management. It is not surprising therefore, that the search for solution to the problem of finding optimal capital structure has preoccupied the most authoritative minds in finance and in particular one has to mention - the Nobel prize laureates - Merton Miller and Franco Modigliani.

These scientists have reached a paradoxical conclusion (the result known as the Modigliani - Miller theorem), that under conditions of perfect market (most importantly, perfect information) and in the absence of taxes and transaction costs, as well as under conditions of equal access to credit by companies and people, capital structure does not affect the price of capital. Therefore, in their opinion, capital structure by itself does not influence the price of capital, thus financial managers should not be preoccupied with the search for the possibilities of increasing company's value, but rather concentrate on the effective asset management [2].

Turning to practical experience, however, one can see that the managers of most companies pay significant attention to optimizing capital structure, which, as has been mentioned before, is still one of the main tasks and objectives of financial management. Evidently, the explanation for this behavior lies in the fact that real conditions, under which companies operate, are quite far from the circumstances of ideal markets, which have been postulated by Modigliani and Miller in the assumptions of Modigliani - Miller theorem. Ideal markets currently do not exist, there are both transaction costs and various distortions introduced by taxation, and finally, physical entities have more limited access to credit resources than companies do.
Taking into the account all of the abovementioned, it is possible to conclude that optimizing capital structure can make a tangible contribution to the lowering of the price of capital and increase the value of the company. One of the main examples of this effect is the possibility in most jurisdictions to include the interest on taken loans in the costs of the company, which means that they are excluded from the taxable income of the company. At the same time, dividends are paid from the net profit; therefore they do not offer the company and its owners such benefits in terms of taxation.

Thus, one can conclude, that expanding the proportion of borrowed financing to a reasonable extent can lead to the lowering of the total price of attracted capital. Financial managers are in part preoccupied with determining the level of that extent that is developing the target capital structure for the company, which is likely to be different for different companies, depending on the specifics of their operation, as well as the financial markets they interact with. The possible causes for these differences are outlined below.

This problem is important not only for the company, which is attracting capital, but also for the potential investors. Due to the increased tendency for liberalization of the capital markets and technological developments that increase access to and the speed of information exchange, capital is virtually free to move to the parts of the globe, where resources can be used most effectively. Under these conditions, the questions of developing and implementing the best financing strategy, where the problem of optimal capital structure takes center stage, are vital for any company.

The problem can also be formulated in the following way: how does one determine the optimal proportion between equity and borrowed capital, which minimizes the total cost of capital for the company? The most commonly accepted viewpoint is that, when the proportion of borrowed capital is low, compared to the proportion of equity, the first way of financing is cheaper, because it has lower risk level. Therefore, by using the borrowed capital, one can lower the total cost of capital. If the proportion of the borrowed capital, compared to equity, is growing, then interest payments begin to take up an increasing proportion in the expected profits of the company. The risk both for shareholders and creditors begins to grow, and therefore, on account of risk premium, they demand larger income. Even if interest payments remain the primary destination of profit allocation, there will be a risk that, when the proportion of borrowed capital reaches a certain high level, profits decrease and are no longer sufficient to cover interest payments. 
In order to solve the problem of optimum capital structure, which is described above, a certain process for optimizing company' capital structure can be developed. The beginning stages of this process are:

- Analysis of the company's borrowed capital and equity;

- Evaluation of the main factors, which influence capital structure.

After the initial stages of the process have been completed, one has the available information to attempt to optimize capital structure, using different criteria:

- Minimizing the cost of capital;

- Minimizing the level of financial risks;

- Maximizing the profitability of capital.

In this article, the author will be concerned with the first two stages of the process of optimizing capital structure.

\section{Analysis of the Company's Borrowed Capital and Equity}

This is the primary information gathering stage, which is necessary for the effective planning afterwards. At this stage the objective of the financial manager is to determine the existing tendencies of the development of capital structure, as well as its volume, and their influence on the financial stability of the company. Efficiency of the existing financing arrangements can also be considered at this stage. This stage can conditionally be split into three parts - one more concerned with qualitative characteristics and the two other ones concerned with quantifying the results of the analysis.

The first (qualitative) stage involves comparing the dynamics of the total capital and its ingredients compared to the dynamics of production and sales, assessing the proportion of the borrowed and equity and the history of this proportion. Borrowed capital is further split into long-term and short-term financial obligations, overdue financial obligations are discovered (if they exist) and the causes for the inabilities of a company to meet financial commitments are analyzed.

The second (more quantitative) stage of the analysis uses the system of coefficients of financial stability of a company to asses the capital structure. This stage utilizes well known financial indicators, such as different liquidity ratios [3].

The purpose of these coefficients of financial stability is to show the degree of the possible risk of bankruptcy of a company that is related to the use of borrowed financial resources. Obviously, if the company does not use any borrowed funds the risk of bankruptcy related to the usage of borrowed funds is equal to zero. As the proportion of the borrowed capital grows, the risk of bankruptcy is also growing, because of the increase in company's liabilities. Therefore, financial coefficients are mostly of interest for the existing and potential creditors of the company.

As a rule, debts to the ordinary creditors are paid, after the payment of taxes, wages and repayment of claims of secured creditors, who provided loans secured by collateral, such as office space or production machinery. The assessment of company's liquidity helps to make a judgment of the extent to which the ordinary (unsecured) creditor is protected.

Another group of financial coefficients helps to determine the dependency of the company on the borrowed capital (how does the company use financial leverage) and therefore to compare the positions of the creditors and owners of the company. The concept of financial leverage states that the successful use of the borrowed capital leads to the increased profits for the owners of the company, since they have the rights to profits obtained by the use of the borrowed capital, which leads to the increase in company's equity.

However, one has to keep in mind, that any loans and interest on those loans have to be repaid even in case, if the profits obtained are not enough to cover these payments. The owners of the company always have to cover the claims of the creditors, which can negatively influence the equity of the company. The concept of leverage is therefore a double-edged sword. The positive and negative influence of the financial leverage grows in proportion to the volume of the borrowed capital that the company uses. The risk of the creditor, therefore, also grows in tandem with the risk of the owners. The coefficients in this group include:

- Debt to assets ratio is the primary and the most utilized evaluation, which can be made, while evaluating the risk of the creditor. This indicator is calculated by the following formula:

\section{Debt to assets ratio $=$ Total Liabilities $/$ Total Assets}

This indicator is calculated for a point in time, but not for a period. It calculates the share of the "other money" in the total amount of claims on the assets of the company. The higher this coefficient, the larger is the probable risk for the creditor. Let us assume, for example, that the results of the computation for the last three years of business operation of Company $\mathrm{X}$ are presented (along with several other financial 
coefficients that will be discussed below) in Table 1 .

This data indicates that around $50 \%$ of the financial resources at company's disposal come from the borrowed resources. Naturally, a question arises: whether this is a positive or negative development? This question does not have a unanimous answer. Everything depends on the preferences of company's owners and its management, most importantly, on their attitude to risk. Managers, who are risk averse, will try to achieve lower levels of this indicator and will attempt attracting additional finance by issuing new shares. One the other hand, managers and owners who are risk neutral and have higher tolerance for risk, will attempt to boost the share of borrowed funds in assets, aiming to exploit the positive aspects of financial leverage and increase profits.

If a company has a well-developed and positive credit history, creditors will gladly lend money, in spite of the large value of the debt to asset ratio. In practice, this indicator can reach levels as high as $90 \%$.

If the company is not considered a "reliable borrower" (not necessarily due to a failure to repay obligations, but, for example, due to the fact that the company is newly created), then the debt to asset ratio of $50 \%$ can be considered critical for the company, in a sense, that after that level, the prospective of obtaining additional loan financing is significantly decreased.

However, one cannot simply conclude that the coefficient described above is a perfectly correct evaluation of the company's abilities to repay its debts. The reason for this is that the asset book value (used to calculate the coefficient) does not always correspond to the real economic value of those assets or even the value, for which they can be sold quickly. Apart from that, this coefficient does not provide any insights on the possible changes in profits of the company, which can influence the payments of interest and the repayment of the principal.

- Debt to capital ratio is an indicator that is computed based on the proportion between the size of the long-term debt and the size of the capital. This indicator presents the analyst with a clearer picture of risk due to the usage of borrowed funds. In this calculation, capital is defined as the total amount of company's capital (including common and preferred stock as well as long-term debt), minus the short term liabilities. The coefficient can be computed according to the following formula:

\section{Debts to capital ratio = Long-term Liabilities / Total capital}

By definition, capital in this case includes the amount of long-term claims on company's assets by the creditors as well as the owners but does not include current (short-term) claims. The total amount of those corresponds to what can be called net assets", if no adjustments have been made, such as excluding deferred taxes from the calculation. For example, if deferred taxes have not been excluded a calculation of this indicator for the company leads to the results that are summarized in the second line of Table 1.

Debt to capital ratio tends to get lower over time, due to the fact that part of the long-term financial liabilities is usually repaid over time. This coefficient gets a large share of attention, because a lot of contracts on lending, whether it's the private company or a public corporation being financed, contain certain conditions that regulate the maximum share of company's borrowed capital, which is expressed in terms of the debt to capital ratio.

The same characteristics, but in a different ratio, are represented by the indicator of the debt to equity ratio. This indicator is directly related to the previous indicator and can be calculated, with the help of the previous indicator. Consider the following calculation:

Let $D$ be the amount of the long-term debt in the company, $E$ - the size of company 's equity, then $D C-$ debt to capital ratio can be calculated by the following formula:

$$
D C=D /(D+E)
$$

If we now let, $D E$ to denote debt to equity ratio, such as $D E=D / E$, then by simple algebraic manipulation, we obtain that:

$$
D E=D C /(1-D C) .
$$

The value of the debt to equity ratio for Company $\mathrm{X}$ is also summarized in Table 1.

Table 1. Values of Financial Coefficients for Company X

\begin{tabular}{|c|c|c|c|}
\hline Financial Coefficient & January $1^{\text {st }}, 2003$ & January $1^{\text {st }}, 2004$ & January $1^{\text {st }}, 2005$ \\
\hline Debt to assets ratio & $48.0 \%$ & $49.5 \%$ & $45.5 \%$ \\
\hline Debt to capital ratio & $24.3 \%$ & $21.5 \%$ & $18.0 \%$ \\
\hline Debt to equity ratio & $32.1 \%$ & $27.4 \%$ & $22.0 \%$ \\
\hline
\end{tabular}


Using this indicator, one can easily interpret the condition of capital structure. A potential creditor, for example, can clearly see that on January $1^{\text {st }}, 2005$, company's X long term debts are around $22 \%$ of the size of the equity. If the company $\mathrm{X}$ has sufficiently high liquidity (that is the ability to repay its shortterm obligations), then it can be granted additional credit. Note, that if one only had the access to the first ratio considered (debt to assets ratio), it would not have been possible to make that conclusion, because there long-term debts were not separated from the short-term ones.

A number of other ratios can be considered, for example, the previous calculation of the debt to equity ratio can be modified to include current liabilities (short term debts) divided by the total equity of the company. This coefficient represents a yet another way to indicate relative shares in claims of creditors and owners and is also used to determine the dependency of the company on borrowed capital. If the values of this coefficient are significantly higher than the values of the previously described coefficients, then there's a large share of the shortterm liabilities in the overall capital structure.

Another possible coefficient used in financial ratio analysis is capital to asset ratio, which indicates the share of company's equity in its assets.

The existence of such a variety of coefficients serves to underscore how carefully the rules of financial analysis and conditions that regulate credit access are developed. However, coefficients only serve to provide the first overall idea of the risks and rewards that stem from the usage of the borrowed capital.

On the third (also quantitatively oriented) stage of the analysis, the objective of the analyst is to assess the efficiency of capital utilization as a whole, as well as the efficiency of utilizing separate sources of capital. This stage also envisages a set of useful quantitative indicators, which can be calculated and analyzed [4]. These indicators can include:

- Capital intensity of production. This indicator aims to show the amount of capital necessary to produce one unit of firm's output. It is mostly dependent on the nature of firm's output (for example, clothes vs. electronics manufacturing). Information about capital intensity is vital for planning firm's capital requirements in the future.

- Capital turnover period. This coefficient is the number of days, in which the company turns over capital, that is capital generates the projected amount of profit. This coefficient can be computed for equity, borrowed capital as well as the total capital of the company. Since every turnover of capital means generating a certain amount of profit, the lower the company manages to make capital turnover period, the more efficient is capital utilization.

- Return on equity. This indicator characterizes the amount of earnings generated by a single unit of equity and is one of the most important pieces of information, necessary for decisions on optimizing capital structure.

- Return on investment (total capital). This indicator is somewhat equivalent to return on assets indicator, characterizing economic efficiency of total capital utilization, by measuring earnings per one unit of capital.

- Capital productivity. This indicator measures the units of output produced due to utilizing one unit of capital and therefore can serve as an indicator of efficiency of company's operation.

Having considered all of the three stages of the analysis of equity and borrowed capital, the author can now turn to the second stage of the analysis - evaluation of the main factors, which influence capital structure. It has already been mentioned that it is not possible to formulate a sure recipe for optimal capital structure not only for companies that are part of the same industry, but even for the same company working under different market conditions or at a different point in its lifetime. Practical experience, however, has developed a set of subjective and objective considerations (factors), which should be taken into account in purposefully creating capital structure, that would be optimal and take into account all of the specifics of the particular company and its operating conditions [4].

These factors can be broadly separated into the sets of external and internal factors. External factors include:

- Conditions on the market for company's output. The main article of interest in this case is the level of demand for the company's product and its stability. The more stable are the conditions on the company's primary markets, the safer and potentially more profitable it is to use borrowed capital. On the other hand, when market conditions deteriorate and sales volume falls, company's increased use of the borrowed capital can lead to the accelerated loss of earnings and an increased risk of default. Under these circumstances financial managers should attempt to lower the use of borrowed capital, lowering the leverage of the company. 
- Conditions on financial markets. A wide variety of conditions on financial markets determine the price of borrowed capital and make it larger or smaller at a certain point in time. If the price of capital is growing (sometimes expressed by rising interest rates), the difference in costs between borrowed capital and equity can become so large, that the use of borrowed capital will lead to a sharp decrease in profitability and the companies might even start taking losses due to high interest payouts. On the other hand, if the price of borrowed capital falls dramatically, the efficiency of its utilization can fall. Often, cheap access to credit can motivate companies to engage in ever riskier behavior, which is not good for the health of the economy long-term. Finally, conditions on the financial markets affect the cost of raising new share capital as well, because as interest rates rise, investors will demand higher returns on the invested capital.

- Company's image on the financial market. When evaluating the credit-worthiness of a particular company, creditors typically have their own well-developed guidelines, which are not always the same across different types of creditors and often differ from the internal assessment criteria of the company. It is conceivable that in some cases, in spite of high financial stability of a company overall, creditors might have different criteria in mind that create a negative image for the company and consequently lower its credit worthiness. Naturally, this leaves a negative impact on the possibility of attracting borrowed capital and lowers the company's ability to quickly satisfy its capital requirements by relying on external sources.

- Tax policy of the company's country. It has been mentioned before that use of borrowed capital has tax advantages, because the company is able to deduct loan interest from its taxable income. If the corporate rate for income tax is low, companies have lower incentives to attract borrowed capital, making the issuing of the new share capital correspondingly more attractive. At the same time, when the corporate income tax rate is high, the efficiency of attracting new borrowed capital rises significantly. In Latvia, corporate income tax rates are comparatively low, which is likely to make tax considerations secondary for the companies when deciding on capital structure.
Finally, one should consider the following internal factors, which help to shape company's optimal capital structure:

- Specifics of the industry the company is operating $i n$. The nature of the industry obviously determines the nature of company's assets and their liquidity. Companies, whose production is capital intensive, often have a larger portion of less liquid means of production on their balance sheets, which means that they are likely to have lower credit ratings and rely more on issuing share capital to finance their operations. Also, one should note that the nature of the industry determines the length of the operations cycle of a company. The shorter the operations cycle, the better one can utilize borrowed capital.

- The attitude of company's owners and managers towards risk. Since capital structure is intimately tied to varying levels of risk, risk tolerance of company's personnel plays an important role in capital structure. If the higher levels of management have high levels of risk tolerance, they will be inclined to use borrowed capital to the maximum possible extent, in order to obtain the highest return on equity, without regarding possible elevated risk. On the flipside, if the higher management is increasingly risk averse, company's capital structure will be shaped in a conservative manner, relying mostly on issuing new equity.

- Operating leverage for the company. A company can increase its earnings due to the application of both operating and financial leverage. Therefore, companies with a growing sales volume, but, who have for a variety of possible reasons, low operating leverage, with all other conditions being equal, can allow themselves to increase financial leverage that is increase the proportion of borrowed funds in the total capital structure.

- Profitability of company's operations. If company's profitability is high, the company's credit rating and image on the financial markets is likely to grow, which means increased potential to attract borrowed capital. In practice, however, this increased potential can often remain unused for the simple reason, that when a company really does have high profitability it can satisfy its capital demands by moving higher retained earnings to capital. In those cases, company's owners prefer to invest their profit in the 
company, which has high returns on capital, which can, all other things being equal, lower the proportion of borrowed funds.

- The amount of concentration of the equity capital. In order to preserve controlling interest in the company, company's owners may often be unwilling to issue new share capital to external sources. The objective of the preservation of financial control over the company then becomes a factor in favor of satisfying growing capital requirements by means of borrowing. In countries whose financial markets are more developed than Latvia's other options are possible, such as shares or other securities without the implication of voting rights, etc.

- The stage of the company's life cycle. Companies have clearly outlined periods of development, for example, a growing company, with a newly developed competitive product, can let itself use a large share of borrowed funds in its capital, even thought it may come at a higher than average price, reflecting the increased risk. Companies, whose markets and products are more mature would do better to be more risk averse and use more of the share capital.

\section{Conclusion}

In this article, the author had looked at the first two stages of developing an optimal capital structure, which stress the importance of gathering reliable financial information about the company (enabling calculation of the ratios mentioned in the article) and performing risk analysis (relying in part on the external and internal factors described in the article) in order to decide on the optimal capital structure. In Latvia, where the economy is currently growing very rapidly, company's managers might have incentives to increase their leverage (share of borrowed capital), hoping for the high level of domestic demand to continue and help them obtain higher returns on capital. One has to caution, however, that economic growth has an inevitable tendency to at least slow down over time. Managers need to take that into account, when planning capital structure and therefore avoid increasing their leverage to dangerous levels.

\section{References}

1. Saksonova, S. Latvijas komercbanku aktīvi-attīstība, struktūras pārvaldības iespējas. Rīga: Latvijas Zinātņu Akadēmijas Ekonomikas institūts, 2003.

2. Модильяни, Ф.; Миллер, М. Сколько стоит фирма? Москва: Дело, 1999.

3. Myers, S. C. The Search for Optimal Capital Structure / Financial Strategy Adding Stakeholder Value. Ed. Rutterford J.: John Wiley and Sons, 1998.

4. Бланк, И. А. Финансовый менеджмент. Киев: Никацентр, Эльга, 1999. 